\title{
Congressional Investigations and Judicial Review: Kilbourn v. Thompson Revisited
}

\author{
Gerald D. Morgan*
}

A legislative committee of inquiry vested with power to summon witnesses and compel the production of records and papers is an institution rivaling most legislative institutions in the antiquity of its origin. ... Prior to the adoption of our Constitution colonial assemblies frequently assumed authority to punish for contempt any person who refused to appear in answer to a summons or who failed to disclose information required for the effective administration of Government. ${ }^{1}$

For almost 100 years following the adoption of the Constitution this institution of inquiry flourished virtually free from judicial supervision or control. Indeed, in 1821, Chief Justice Marshall's court, in Anderson v. Dunn, ${ }^{2}$ intimated that the institution was not subject to control by the judiciary, and a similar intimation is found in Ex parte Nugent, ${ }^{3}$ decided in 1848 by the circuit court of the District of Columbia, in which it was held by the court, after an exhaustive review of the English authorities, that the court had no power in a habeas corpus proceeding to go behind a warrant of the Senate ordering a witness committed for contempt.

It was not until 1881 in Kilbourn v. Thompson ${ }^{4}$ that the Supreme Court undertook to pass upon the validity of a "judgment" of the House of Representatives adjudicating a witness to be in contempt of the authority of the House, ${ }^{b}$ and to do so in a proceeding (false

* Assistant legislative counsel U.S. House of Representatives, 1935-1945. Private practice Washington, D.C. 1945-.

1 Fields v. United States (App. D. C. 1947) 164 F. (2d) 97, 99, cert. denied, (1948) 332 U.S. 851.

2 (U.S. 1821) 6 Wheat. 204.

3 (N. D. Il. 1871) 18 Fed. Cas. 483, No. 10,377.

4 (1881) 103 U.S. 168.

- Because the power of legislative bodies to punish for contempt is like the power of the courts to do the same thing, the power in legislative bodies has sometimes been characterized as "judicial" in nature. Landis, Constitutional Limilations on Congressional Power of Investigation (1926) 40 HARv. L. Rev. 153. Calling it that may have had some influence on the assumption of judicial control over it. Whatever its character, it seems to be a power that legislative bodies exercised for several centuries before the adoption of our Constitution, and for over half of our own Constitutional history, without judicial interference. 
imprisonment) that constituted a collateral attack upon that judgment. The "judgment" was held void on the ground that the subject matter of the inquiry was one on which Congress could not validly legislate. Thus began the doctrine whose effect was to treat the Senate and House of Representatives, when exercising an inherent power at the very threshold of the legislative process, as having a status analogous to that of an inferior court of limited or special jurisdiction. ${ }^{8}$

Indeed for some 46 years following Kilbourn v. Thompson, because of the broad sweep of its reasoning (and also, as has since been shown, ${ }^{7}$ by reason of an incorrect view taken by the Court as to the origin of the inquisitorial power possessed by the British Parliament), the very existence in this country of a power in the Senate and House of Representatives to compel testimony and punish for contempt in aid of the legislative function was in grave doubt. And this doubt was not finally resolved until a short 22 years ago when the Court in $M C$ Grain v. Daugherty - upon review of a decision of a district court in a habeas corpus proceeding-held that the Senate was acting within its lawful authority in arresting the brother of former Attorney General Daugherty for refusing to respond to a subpoena directed to him by a Senate committee investigating the administration of the Department of Justice.

While much has been written on the subject of "judicial supremacy" as applied to the power of the courts to invalidate laws after the legislative process has been conpleted, little attention has been paid to the proper relationship of the courts to the legislative branch of the Government at the beginning of the legislative process-i.e., in the field of legislative inquiries. It seems desirable that a preliminary analysis, at least, be made of that relationship, ${ }^{9}$ since legislative inquiries sometimes determine whether the lawmaking process shall begin at all, and judicial intrusion into such inquiries can have the effect

\footnotetext{
B Infra note 12.

7 Landis, op. cit. supra note 5; Potts, Power of Legislative Bodies to Punish for Contempt (1926) 74 U. of PA. L. Rev. 691.

8 (1927) 273 U.S. 135.

${ }^{9}$ Such an analysis seems particularly apt in view of the decision of the Supreme Court this past term in Christoffel v. United States (1949) 338 U.S. 84. For the Court in holding in that case that (1) the status of a standing committee of the House of Representatives as a "competent tribunal" within the meaning of the District of Columbia perjury statute, and (2) the integrity of the committee's records as to the presence of a quorum, could be impeached by parol evidence, has opened up a veritable Pandora's box of new implications of vastly extended judicial supervision and control over every step of the legislative process.
} 
of stopping that process before it can ever get started. After it starts, courts uniformly maintain a hands-off attitude until a finished product in the form of a law comes into being. ${ }^{10}$ Why do they intrude when the exercise of the power of investigation is involved-and do it, as they necessarily must, in collateral proceedings?

Kilbourn v. Thompson ${ }^{11}$ started the practice. But while the Court was aware in that case that a collateral attack was being pressed against a "judgment" of the House of Representatives, it evidently did not consider that it was exercising any greater jurisdiction to allow such attack than it would have exercised in the case of a judgment of contempt by a court of general jurisdiction. For even courts of general jurisdiction inust have "jurisdiction" over the person and the subject matter in order to immunize their judgments from collateral attacks. ${ }^{12}$ The Court in Kilbourn v. Thompson merely held that Congress had no jurisdiction to legislate on the subject matter into which the committee of the House of Representatives was mquiring, and that hence the committee had no jurisdiction to inquire on that subject matter. In so holding, however, the Court could have had but little appreciation of the implications of its assuming jurisdiction to determine the limits of the power of Congress to enact legislation before that power had ever been exercised. Certainly at the time of Kilbourn $v$. Thompson, there was no appreciation at all of the role that facts can play in marking out the scope of the legislative power of the United States. ${ }^{18}$

10 Goodland v. Zimmerman (1943) 243 Wisc. 459,10 N.W. (2d) 180; The People v. Mills (1902) 30 Colo. 262, 70 Pac. 322; State ex rel. Carson v. Kozer (1928) 126 Orc. 641, 270 Pac. 513; Bowe v. Secy. of the Commonwealth (1946) 320 Mass. 330,69 N. E. (2d) 115.

11 Supra note 4.

12 Chicot County Dist. v. Bank (1940) 308 U. S. 371, and cases cited therein. "Jurisdiction," as applied to the courts, however, includes jurisdiction to decide whether jurisdiction exists. Swift \& Co. v. United States (1928) 276 U.S. 311 ; United States v. Umited Mine Workers of America (1947) 330 U.S. 258. A judgment adjudicating a criminal contempt cannot be successfully attacked even directly on the ground that the Court had no jurisdiction, if the Court had jurisdiction to decide whether it did or did not have jurisdiction. United States v. Shipp (1906) 203 U.S. 563 ; United States v. United Mine Workers of America, supra, opimion of Frankfurter, J. It is believed that Kilbourn v. Thompson fell into error in its failure to recognize that the legislative power nust necessarily include the power (1) to decide in the course of the legislative process whether "jurisdiction" exists to exercise the power, and (2) to adduce facts for that purpose.

13 Cf. National Labor Relations Board v. Jones \& Laughlin Stecl Corp. (1937) 301 U.S. I; Home Building \& Loan Ass'n. v. Blaisdell (1934) 290 U. S. 398; Lockner v. New York (1905) 198 U.S. 45; the influence of the factual brief of Mr. Louis D. Brandeis filed in Muller v. Oregon (1908) 208 U.S. 412. 
But more important, Kilbourn v. Thompson indicates a lack of understanding as to just what the legislative function is. Legislatures exist not merely to enact laws. They have the equally important function of determining that laws should not be enacted ${ }^{14}$ and their decisions in the performance of this latter function must in the nature of things frequently be influenced by consideration of whether or not the power to legislate exists. Yet Kilbourn v. Thompson would prevent the legislature from gathering the information that it believes will enable it to make such decisions, to make them intelligently, and to persuade others that such decisions are correct. ${ }^{15}$

To be sure there has been criticism-much of it justified-of the manner in which committees of Congress have exercised the inquisitorial power, but there has likewise been criticism of the attempts that have been made to restrict the power. ${ }^{16}$ Desire to pumish a blackguard or rescue a saint, however, should not affect decisions on such great questions as the distribution of governmental powers under our Constitution. ${ }^{17} \mathrm{It}$ "'must be remembered that legislatures are ultimate guardians of the liberties of the people in quite as great a degree as the courts." 18

Since Kilbourn v. Thompson there have been only four cases" in the Supreme Court in which attacks have been pressed against "judgments" of the Senate or House of Representatives, and only one $\mathrm{m}$ which the attack was successful, ${ }^{20}$ so there may yet be time for the Court to re-examine the basis for its assumption of the power of

14 In many Iegislative bodies, the rules of procedure require the standing committees to consider every bill or resolution referred to them and to report either favorably or adversely thereon. Does Kilbourn v. Thompson mean that a legislature has no Constitutional power to compel its committees even to consider what perchance the legislature itself might lack power to enact? $C f$. Bowe v. Secy. of the Commonwealth, supra note 10, involving an attempt to seek an injunction against an initiative on the ground that the law if enacted by the people would contravene the Constitution.

15 Supra note 12.

16 Gellhorn, Report on a Report of the House Committee on Un-American Activities (1947) 60 HARv. L. REv. 1193; Frankfurter, Hands Off Investigations, May 1924 NEw REPUBLIC; Coudert, Congressional Inquisition vs. Individual Liberty (1929) 15 VA. L. REv. 537.

17 Cf. Frankfurter dissenting in Davis v. United States (1946) 328 U.S. 582, 597.

18 Missouri Kansas, \& Texas Ry. v. May (1904) 194 U. S. 267.

19 Marshall v. Gordon (1917) 243 U.S. 521; McGrain v. Daugherty, supra note 8; Barry v. U.S. ex rel. Cunningham (1929) 279 U.S. 597; Jurney v. McCracken (1935) 294 U.S. 125. Cases involving prosecutions under section 102 of the Revised Statutes (2 U.S. C. 192) are in this paper regarded differently. See infra note 21.

20 Marshall v. Gordon, supra note 19. For a discussion of this case see Potts, op. cit. supra note 7 . 
judicial review. A distinction must be made between these four cases, involving, as they do, "judgments" of the Senate or of the House of Representatives itself-i.e., where the Senate or House adjudicates and punishes a contempt-and the cases $^{21}$ arising out of prosecutions under section 102 of the Revised Statutes ${ }^{22}$ for refusing to answer "pertinent" questions before a duly authorized committee of the Senate or House. Where section 102 of the Revised Statutes is invoked, neither the Senate nor the House as such is required to make any determination or adjudication, or render any "judgment," at all. Whether its committee was inquiring on the particular subject that was referred to it, or whether the questions propounded by the committee to the particular witness were pertinent, are matters that the legislative body as a whole may never even have considered. ${ }^{23}$ Moreover, insofar as the question of pertinency is concerned, section 102 of the Revised Statutes (by reason of the form in which it is drafted) makes this a question of law rather than one for legislative determination - that is to say, the crime defined in that section is the refusal to answer questions that as a matter of law are pertinent to the inquiry. Thus, in prosecutions under that section, what is or is not pertinent can only be determined judically.

Because of the different problem-at least as respects the question of pertinency-involved in the cases arising under section 102

21 In re Chapman (1895) 156 U.S. 211. In re Chapman (1897) 166 U.S. 661 ; Henry v. Henkel (1914) 235 U.S. 219; Sinclair v. United States (1929) 279 U. S. 263 ; Christoffel v. United States, supra note 9.

${ }^{22} \mathrm{Sec} .102$. Refusal of Witness to Testify. Every person who having been summoned as a witness by the authority of either House of Congress, to give testimony or to produce papers upon any matter under inquiry before either House, or any committee of either House of Congress, willfully makes default, or who, having appeared, refuses to answer any question pertinent to the question under inquiry, shall be deemed guilty of a misdemeanor, punishable by a fine of not more than one thousand dollars nor less than one hundred dollars, and imprisonment in a common jail for not less than one month nor more than 12 months. REv. STAT. \& 102 (1878), 2 U.S. C. \$ 192 (1946).

${ }^{23}$ Section 104 of the Revised Statutes (1878), 2 U.S. C. \& 194 (1946) provides that when an investigating committee reports a witness' contumacy to the Senate or House, the President of the Senate or the Speaker of the House, as the case may be, shall certify that fact to the district attorney for the District of Columbia, whose duty it is to bring the matter before the grand jury. It has been the practice in the House for the Speaker, if the House is in session when such a report is made, to lay the matter before the House in the form of a resolution authorizing hin, should the resolution be adopted, to certify the facts to the district attorney. It does not seem to be the practice, however, to hear the witness himself in such cases, as would be done were the House itself trying and adjudicating a contempt. If the House is not in session when such a report is made by an investigating committee, the Speaker certifies the facts to the district attorney as a ministerial act under the statute, writhout any prior authorization from the House. 
of the Revised Statutes, those cases will be put to one side temporarily and the discussion confined to the case in which an individual's liberty is restrained by the legislative body itself, either by subpoena, arrest, or confinement for contempt. Such a case might have a history somewhat as follows.

Let us suppose that in June of 1947 there was adopted by the House of Representatives a resolution (that had been introduced several months earlier by Congressman Doakes of Minnesota) providing for the creation of a special committee to investigate a group in Minnesota called the Liberty Bund. It was the purpose of the proposed investigation, according to the terms of the resolution, to determine what the Bund was, who were its inembers, what were its principles, what its connections, etc. The resolution contamed the usual provisions giving the committee subpoena powers, and directing the committee in its report to inake recommendations for such legislation, if any, as the committee deemed advisable.

Congressman Doakes had originally introduced the resolution because of a series of articles in one of the Minnesota newspapers alleging that the Bund was a secret political organization, dominated by a parent organization abroad, and existing for the purpose of seeking to establish, at the propitious moment, a fascist dictatorship in the Umited States. The articles that liad appeared in the Minnesota newspaper were reprinted in many other newspapers throughout the United States, and voters were demanding of their Congressmen that Congress "outlaw" the Bund. The House decided upon an investigation first.

When the investigation was concluded, it became very clear that the Bund was not the sinister organization that it had been alleged to be, but was an association of persons of German descent in Minnesota who had associated themselves together for the purpose of preserving old German customs, folklore and traditions. In the commitmittee's report to the House, the committee set forth these facts, stated that it was the committee's opinion that Congress was without any power to legislate respecting the Bund, and recommended that even if such power existed no legislation be enacted.

Immediately after the committee was constituted, it issued and served a subpoena upon $A$, who the committee had reason to believe was a nember of the Bund. $A$ appeared in response to the subpoena and was asked:

(1) "Are you a nember of the Liberty Bund?"

(2) "Do you believe in a political system in which there is only one political party?"

(3) "Did you not in August of 1945 discharge ten of your employees for having joined a labor union?" 
$A$ refused to answer the first question on the ground that the committee had no authority under the Constitution to legislate with respect to the Liberty Bund, since that organization was an educational and historical organization, whose activities were confined to the State of Minnesota, and that Congress having no power to legislate, the committee had no power to investigate. He refused to answer the second question on the ground of an asserted right of privacy of political beliefs guaranteed by the First and Fourth Amendments of the Constitution. And he refused to answer the third question on the ground that it was not pertinent to the inquiry.

The committee reported the contumacy of $A$ to the House forthwith, for such action as the House might deem appropriate. $A$ was brought before the House, was asked the same questions by the Speaker (pursuant to the order of the House) and was informed that the House directed him to answer. He still refused, and thereupon he was ordered by the House to be confined in jail until he should be willing to answer.

In order to show the weakness of the Kilbourn rule, the above hypothetical case is constructed upon the assumptions-

(1) That if the Bund were a secret political organization, dominated by a political group in a foreign country and plotting a violent political revolution in this country, Congress had power to legislate with respect to it.

(2) That if the Bund were merely an educational and historical association of persons in Minnesota who had associated themselves together for the purpose of preserving old German customs, folklore, and traditions, Congress had no power to legislate with respect to it.

(3) That at the time of the contumacy of $A$, no facts had as yet been developed as to the character of the Bund.

Kilbourn v. Thompson tells us that unless the subject matter of the inquiry is one on which Congress may validly legislate, the power to inquire on that subject matter does not exist. Yet here we have a case-hypothetical to be sure but not beyond the realm of possibility -in which-under the doctrine of the Kilbourn case-the existence or non-existence of the power to inquire can only be determined by an inquiry itself.

Such a case shows that the auxiliary powers of the legislative branch of the Government-such as the power of inquiry-cannot be limited as set forth in the Kilbourn case; that the "jurisdiction" of the legislative branch must extend at least to determining whether 
or not it does have jurisdiction; and that its auxiliary powers must be available to it to enable it to make that determination.

Now if the power of imquiry does extend to adducing facts for the purpose of enabling the legislative body to determine whether or not it has jurisdiction to legislate, then it is apparent that in our hypothetical case $A$ had no right to remain silent when asked if he was a member of the Liberty Bund. ${ }^{24}$ And since by hypothesis the inquiry was one that the House had the authority to conduct, $A$ likewise had no right to remain silent when asked if he believed in a political system in which there is only one political party, for affairs are not private where their disclosure is pertinent to a lawful investigation. ${ }^{25}$ The matter of $A$ 's refusal to answer the third question will be discussed in a moment.

The Supreme Court three years ago gave indication it recognized that the limitations imposed upon the legislative power of inquiry by Kilbourn v. Thompson-as well as by the subsequent cases-are not realistic. The case was Oklahoma Press Publishing Co. v. Walling, ${ }^{26}$ arising under the Fair Labor Standards Act. ${ }^{27}$

Mr. Walling, the Administrator of the Wage and Hour Division of the Department of Labor, had issued and served on the Oklahoma Press Publishing Company, pursuant to his authority under the Fair Labor Standards Act to investigate violations of the Act, a subpoena directing the production by the company of certain of its recordsincluding records which would indicate whether or not the company had a sufficient relationship to interstate commerce to bring it within the jurisdiction and coverage of that Act. The company, opposing the subpoena, contended, among other things, that at least "probable cause" for jurisdiction over it inust be shown before it could be lawfully required by subpoena to produce its records. The Supreme Court regarded the case as involving not merely a narrow issue as to the application of the Fair Labor Standards Act, but as bringing imto question Congress' own power to make investigations..$^{28}$ And it then held that "probable cause" for jurisdiction did not have to be shown

24 McGrain v. Daugherty, supra note 8.

25 Sinclair v. United States (1929) 279 U.S. 263. See text infrc at note 40 and Nutting, Freedom of Silence (1948) 47 MTcr. L. REv. 181, 213.

26 (1946) 327 U. S. 186.

2752 Stat. 1060 (1938), 29 U.S. C. $\S \S 201-219$ (1946).

28 "For to deny the validity of the orders would be in effect to deny not only Congress' power to enact the provisions sustaining them, but also its authority to delegate effective power to investigate violations of its own laws, if not perhaps also its own power to make such investigations." Supra note 26 at 201. 
in order to validate the subpoena - that the Administrator had juristion to compel production of documents in order that he might determine whether the facts showed a case within the jurisdiction of the Fair Labor Standards Act.

The Court thereupon proceeded to liken the powers of the Administrator (granted to him by Congress) to the inquisitorial power of a grand jury or the discovery powers of a court of equity, and in a footnote to its opmion stated that the investigating power of Congress itself was of the same character. ${ }^{29}$ Now it seems reasonable to conclude that if Congress can vest in the Administrator of the Wage and Hour Division the power to make investigations, whose scope is limited only by the broad grant of his authority in section 11(a) of the Fair Labor Standards Act to make investigations of violations of the $\mathrm{Act}^{30}$ and compel testimony therein without any prior showing, even of "probable cause," that the person whose testimony is required is subject to the jurisdiction and coverage of the Act under which the Administrator operates-or indeed is even subject to the jurisdiction of the legislative power of the United States under the Commerce clause of the Constitution-Congress itself may do the same in conducting its own investigations in aid of its own powers; and that the inquisitorial power of Congress extends to adducing facts which it can use as a basis for determining whether or not it has any power to legislate.

But does not the Oklahoma Press case do more? Consider for a moment the inquisitorial power of grand juries, to which the Court likened the inquisitorial power of Congress. The powers of a grand jury are vast. Some of them are described by the Court in Blair $v$. United States, ${ }^{31}$ cited with approval in the Oklahoma Press case.

He [a witness called to testify before a grand jury] is not entitled to raise objections of incompetency or irrelevancy, such as a party might

\footnotetext{
29 Supre note 26 at 216, n. 55 .
}

${ }^{30}$ Sec. 11. (a) The Administrator or his designated representatives may investigate and gather data regarding the wages, hours, and other conditions and practices of employment in any industry subject to this Act, and may enter and inspect such places and such records (and make such transcripts thereof), question such employees, and investigate such facts, conditions, practices, or matters as he may deem necessary or appropriate to determine whether any person has violated any provision of this Act, or which may aid in the enforcement of the provisions of this Act. 52 Stat. 1060 (1938), 29 U.S.C. \& 211(a) (1946).

31 (1919) 250 U.S. 273, 282. 
raise, for this is no concern of his. Nelson v. United States, 201 U.S. 92, 115.

On familiar principles, he is not entitled to challenge the authority of the court or of the grand jury, provided they have a de facto existence and organization.

$H e$ is not entitled to set limits to the investigation that the grand jury may conduct. The Fifth Amendment and the statutes relative to the organization of grand juries recognize such a jury as being possessed of the same powers that pertained to its British prototype, and in our system examination of witnesses by a grand jury need not be preceded by a formal charge against a particular individual . ... It is a grand inquest, a body with powers of investigation and inquisition, the scope of whose inquiries is not to be limited narrowly by questions of propriety or forecasts of the probable result of the investigation, or by doubts whether any particular individual will be found properly subject to an accusation of crime ....

And, for the same reasons, witnesses are not entitled to take exception to the jurisdiction of the grand jury or the court over the particular subject-matter that is under investigation. In truth it is in the ordinary case no concern of one summoned as a witness whether the offense is within the jurisdiction of the court or not. At least, the court and grand jury have authority and jurisdiction to investigate the facts in order to determine the question whether the facts show a case within their jurisdiction. ${ }^{31 a}$

The practice of conducting Congressional inquiries through investigating committees can make us lose sight of the fact that the power of imquiry exists in the Senate and House itself, that an investigating committee is merely an agent of the Senate or the House, and that the prescription of the subject matter of the investigation is necessary only because it is necessary to inform the investigating committee of the scope of its agency. There is certainly no Constitutional requirement, however, that would prevent the Senate or House as a whole from conducting an inquiry, and doing so without in any way defining in advance its scope or purpose. Yet if that should be done, the inappropriateness of judicial review would at once become apparent. For the court would be faced with the following impossible alternatives:

(1) Presuming that the legislative body did not have a bona fide legislative purpose in mind; or

(2) Passing upon whether particular information sought by compnlsory process was pertinent to any one of myriad subject

31a Emphasis added. 
matters with respect to which Congress might validly legislate, or, if not, whether it was pertinent to a determination by the Senate or House that Congress lacked power to legislate on any one of myriad other subject matters.

In any event under alternative (2), the court would hardly be exercising judicial power, for what is or is not pertinent to legislative decisions would seem to be essentially a question of legislative judgment.

If judicial review would be inappropriate if the Senate or House itself should conduct the inquiry and not define the scope or purpose thereof, is it nevertheless appropriate where the Senate or House exercises the inquisitorial power through a committee created by a resolution that sets forth the scope of the committee's powers?

Let us return for a moment to the hypothetical case of the investigation of the Liberty Bund. It will be recalled that the committee asked $A$ if he had not at one time discharged ten of his employees for having joined a labor union-a question that does not appear to be pertinent to the matter into which the committee was authorized by the House to inquire. But it is a question dealing with a subject matter on which Congress may certainly lawfully legislate, ${ }^{32}$ if $A$ 's business has a sufficient relationship to interstate or foreign commerce.

When $A$ refused to answer this question, let us assume that the following transpired:

The committee reported $A$ 's refusal to the House. Upon receiving the report of its committee, the House ordered the Sergeant-at-Arms to bring $A$ before the House to show cause why he should not be punished for contempt. $A$ appeared before the House in the custody of the Sergeant-at-Arms, and argued to the House that he had respectfully declimed to answer the question because it was not pertinent to the committee's inquiry. Thereupon the House by its vote directed the Speaker to propound the same question to $A$ and to inform him that the House ordered him to answer. When the Speaker propounded the question, $A$ still refused to answer. The House then by its vote directed the Sergeant-at-Arms to confine $A$ in jail until he should be willing to answer.

The above-described procedure has been assumed because it is substantially the same procedure followed when Kilbourn refused to answer the questions that were propounded to hin by the House committee investigating the failure of Jay Cooke \& Sons. It will be noted that when the committee inade its report to the House, the House did not forthwith determine that $A$ was in contempt for refusing to answer

32 National Labor Relations Board v. Jones \& Laughlin Steel Corp., stıpra note 13. 
before the committee. What the House did was itself to propound the question to $A$, and then, when $A$ refused to answer to the Housebut not before-to order him punished for contenipt of the House. The question was asked by the House itself, not by a committee acting outside the scope of its authorized inquiry.

Let us assume first that $A$ sought judicial relief by habeas corpus when the Sergeant-at-Arms of the House arrested him for the purpose of bringing him for the first time before the House-i.e., the House has not as yet made any determination as to $A$ 's duty to answer..$^{33}$ It seems fairly clear that at this stage of the proceeding, judicial review would be inappropriate if we are correct in our assumption that the House itself may exercise the legislative power of inquiry without defining the scope or purpose thereof. For at this stage of the proceeding all that has been done has been the ordering of $A$ to be brought before the House. ${ }^{34}$ And whether the court thinks the question propounded to $A$ to be pertment or not, up to this point there has been no determination by the House itself on the question of pertinency ${ }^{35}$ Judicial review at this stage would involve an assumption by the court either that (1) the House had no authority under any circumstances to cause $A$ to be brought before it to give testimony, or (2) the House was going to compel $A$ to give information that he had a right to withhold.

Let us next assume that when the Sergeant-at-Arms arrests $A$ for the purpose of bringing him before the House, $A$ decides to "go quietly." Now when the House (with $A$ before it) directs the Speaker to ask $A$ if he did not discharge ten of his enployees for having joined a union, such vote could mean either (1) that the House considered the question pertinent to the investigation of the Liberty Bund, or (2) that, whether or not pertinent to that investigation, the House

${ }^{33}$ It was at this stage of the legislative procedure that $\mathrm{Mr}_{\mathrm{r}}$. Daugherty applied for a writ of habeas corpus. McGrain v. Daugherty, supra note 8 . The question of pertinency was not involved in his case, however, although it would have been if the Senate had commanded him to produce the same records which he had been ordered to produce under the subpoena that had previously been issued and served upon him by the Senate investigating committee.

84 Query whether an arrest may be made by the Senate or House where a previous subpoena has not been issued and disregarded. See McGrain v. Daugherty, supra note 8 .

${ }^{85}$ The House Committee, of course, deemed the question pertinent, else it would not have reported A's refusal to answer to the House. But the Committee has no powers of punishment-nor has it any powers of arrest. The rationale of the principle requiring a party injured by administrative action to exhaust his administrative remedies before seeking judicial relief would seem to be equally applicable in the case of a person claiming to be injured by legislative action who has not exhausted his legislative remedies. 
desired the information in any event for some other legislative purpose. But in either case it is the House-not the committee-that is making the determination. And the House is punishing $A$ not for refusing to answer before the committee, but for refusing to answer before the House-and for refusing to answer a question dealing with a subject matter with respect to which (in our hypothetical case) Congress admittedly has the power to legislate.

In such a case what is there to review? If the House considered the question pertinent to the investigation of the Liberty Bund, and for that reason directed $A$ to answer, has not the House merely exercised a legislative judgment as to what information it - the legislative body-considered that it should have in order to enable it to make a legislative decision on a purely legislative matter? On the other hand, if the action of the House ordering $A$ to answer meant that whether or not the question was pertinent to the investigation of the Liberty Bund, the House desired the information in any event for some other legislative purpose, is not the House in effect conducting an inquiry itself without defining the scope or purpose thereof ${ }^{30}$

Now if, as indicated in the Oklahoma Press case, ${ }^{37}$ the Congressional power of investigation extends to investigating for the purpose of determining if the facts show whether or not Congress can legislate at all, if an investigation does not have to be preceded by the adoption of a resolution defining its scope and purpose, and if the Congressional power of mvestigation is like the inquisitorial power of a grand jury, then it becomes impossible for a court to exercise a power of review with respect to the lawfulness of such investigations, unless the court presumes bad faith on the part of a coordinate branch of the Government. And moreover, questions of "pertinency" in legislative inquiries become questions that by their very nature cannot be determined judicially - they become questions that courts cannot determine at all without in effect rendering advisory opinions as to what facts it would be appropriate for Congress to consider, for the Senate

36 Even if the court is of the opinion that the House's decision on the question of pertinency is clearly and unmistakenly erroneous, the House's crror of decision should not affect its "jurisdiction" to decide so as to make its "judgment" subject to collateral attack. Supra note 12. Craig v. Hecht (1923) 263 U. S. 255. This case involved section 268 of the Judicial Code, which grants to district courts "jurisdiction" to punish as criminal contempts only those contempts, among others, as are committed in the presence of the court or so near thereto as to obstruct the administration of justice. The Court hcld that the decision of a district court that a contempt was of this character could not be attacked collaterally through a habeas corpus proceeding. Cf. Craig v. Harney (1947) 331 U. S. 367.

37 Supra note 26. 
or House to consider, in forming a legislative judgment first as to whether it may legislate, next as to whether it should legislate, and finally as to how it should legislate. The exercise of that judgment is made through the collective action of the members, upon their oath of office-substantially the same oath that judges take. And their decision as to what is or is not relevant to the exercise of that judgment should be binding and conclusive upon the world.

What has been the result of the assumption by the courts of the power of judicial review with respect to legislative inquiries? Since the contumacies of M. M. Daugherty and Harry Sinclair, if witnesses have received any comfort at all in the possibility of judicial shelter from persistent legislative inquisitors, such comfort can be a theoretical comfort at best. And since the Oklahoma Press case the possibility of judicial relief is remote indeed. Let us consider for a moment the "rights" that witnesses in legislative inquiries have. The general contours of those rights are set forth in the Sinclair case:

.... that case [the Daugherty case] shows that, while the power of inquiry is an essential and appropriate auxiliary to the legislative function, it must be exerted with due regard for the rights of witnesses, and that a witness rightfully may refuse to answer where the bounds of the power are exceeded or where the questions asked are not pertiment to the matter under inquiry.

It has always been recognized in this country, and it is well to remember, that few if any of the rights of the people guarded by fundamental law are of greater importance to their happiness and safety than the right to be exempt from all unauthorized, arbitrary or unreasonable inquiries and disclosures in respect of their personal and private affairs....

But it is clear that neither the investigation authorized by the Senate resolution above mentioned nor the question under consideration related merely to appellant's private or personal affairs. ${ }^{38}$

What of the right of privacy? Kilbourn v. Thompson ${ }^{39}$ sought to give substance to that right by holding a Congressional investigating committee to be devoid of power to inquire into private affairs and compel their disclosure. The Sinclair case, however, without in any way indicating an intention to dilute the principle of the Kilbourn case, seems to announce that private affairs are not private where their disclosure is pertinent to an investigation that the Senate is authorized to conduct. But the Court, out of respect for determina-

38 Supra note 25 at 291, 294. Emphasis added.

30 Supra note 4. 
tions of a coordinate branch of the Government-plus, possibly, the necessity with which it would otherwise be faced of being required to pass upon the scope of the legislative powers of Congress in advance of their exercise-had previously developed the doctrine that the lawfulness of such an investigation will be presumed - or at least a bona fide legislative purpose will be presumed. ${ }^{40}$ So unless the requirement that the testimony be "pertinent" affords a witness in a legislative inquiry some effective judicial protection of his right of privacy, he must, for all practical purposes, look exclusively to his inquisitors to respect that right.

The Sinclair case tells us that the question of pertimency is a question of law-at least insofar as the crime defined in section 102 of the Revised Statutes ${ }^{41}$ is concerned. But it is a question of law the decision of which in judicial proceedings is in practice left for the most part to the discretion of the trial judge..$^{42}$ If an analogous practice is to govern in the case of legislative inquiries, decisions on questions of pertinency will be left for the most part to the discretion of the legisiative inquisitors. That this is actually what is done is shown by Torensend $v$. United States, ${ }^{43}$ wherein the United States Court of Appeals for the District of Columbia, in reviewing the conviction of Dr. Francis Townsend, under section 102 of the Revised Statutes, for refusing to answer questions put to him by a committee of the House of Representatives investigating old-age pension plans, and for "walking out" of the committee room and refusing to return while he was under subpoena, said:

A legislative inquiry may be as broad, as searching, and as exhaustive as is necessary to make effective the constitutional powers of Congress .... A judicial inquiry relates to a case, and the evidence to be admissible must be measured by the narrow limits of the pleadings. A legislative inquiry anticipates all possible cases which may arise thereunder, and the evidence admissible must be responsive to the scope of the inquiry, which generally is very broad. Many a witness in a judicial imquiry has, no doubt, been embarrassed and irri-

40 In re Chapman (1897) supra note 21 ; McGrain v. Daugherty, supra note 8. As to conclusiveness of the presumption that inquiry has a lawful legislative purpose, $c f$. United States v. Johnson (1943) 319 U.S. 503, questioning whether a recital by grand jury that its indictment was based on an investigation begun during its original term and not on a prohibited investigation begun during an extended term, can ever raise a traversible issue. 41 Supra note 22.

42 Honorable Charles E. Wyzanski, Jr., Congressional Investigations, Record of the Association of the Bar of the City of New York, March 1948, reprinted in (1948) 94 Conc. Rec., A1547.

43 (App. D. C. 1938) 95 F. (2d) 352, 361. 
tated by questions which to him seemed incompetent, irrelevant, immaterial, and impertinent. But that is not a matter for a witness finally to decide. Because a witness could not understand the purpose of cross-examination, he would not be justified in leaving a courtroom. The orderly processes of judicial determination do not permit the exercise of such discretion by a witness. The orderly processes of legislative inquiry require that the committee shall determine such questions for itself. Within the realm of legislative discretion, the exercise of good taste and good judgment in the examination of reitnesses must be entrusted to those who have been vested with authority to conduct such investigations. ${ }^{44}$

Thus even though the question of the pertinency of the information required of a witness is a question of law, and no presumption will be indulged in favor of its pertinency (at least in a criminal prosecution where the presumption of innocence prevails) ${ }^{45}$ nevertheless, by reason of the necessarily wide range of legislative inquiries and the discretion that the courts (even for purposes of the crime defined in section 102 of the Revised Statutes) will entrust to the inquisitors, the witness must in practical effect look exclusively to the inquisitors themselves to protect him agamst being compelled to disclose private affairs that he regards as not being pertinent.

Moreover, whatever judicial protection exists in this regard involves the exercise by the witness of a Hobson's choice. Under the current legislative practice of citing contumacious witnesses for prosecution under section 102 of the Revised Statutes, rather than seeking to pumish them by legislative processes, a witness inust risk a fine or jail sentence, or both, in order to vindicate his position. For should the courts find that the witness was in error in his assertions of irrelevancy his mistake of law is no defense. ${ }^{46}$

While the claim of the privilege against self-incrimination before a Congressional investigating committee has not as yet given rise to any judicial proceeding, ${ }^{4}$ it might nevertheless be appropriate also to consider it at this time. Section 103 of the Revised Statutes ${ }^{48}$ pro-

44 Ibid. Emphasis added.

45 Sinclair v. United States, supra note 21.

48 Ibid.; Townsend v. United States, supra note 43.

47 In United States v. De Lorenzo (C. C. A. 2d, 1945) 151 F. (2d) 122 the witness claimed his privilege, was told that he had no right to claim such privilege before a Congressional investigating committee, then answered incriminating questions, and was later prosecuted. The court found that it was not the witness' answers which had brought about his prosecution, but the information which Congressinan Hebert already had and which prompted Congressman Hebert to ask the incriminating questions.

482 U.S. C. $\$ 193$ (1946). 
vides that the privilege against self-incrimination will not be recognized in Congressional investigations. (Section 859 of the Revised Statutes ${ }^{49}$ makes the testinony inadmissible in criminal proceedings but does not state that the witness shall be immune from prosecution for an offense to which the question relates.) However, despite this provision, during the last two or three years-particularly in the case of the investigations of the Committee on Un-Annerican Activitiesthis privilege has been asserted by witnesses to a greater extent than any other alleged privilege or right.

Yet no instance has been found in which the clain of privilege was not respected by the committee, even where it appeared that there was lack of good faith in claiming the privilege. ${ }^{50}$ In judicial proceedings, a witness who clains his privilege against self-incrimination is not the final arbiter of whether he has properly done so, and it is the function of the court to determine whether there is a reasonable possibility that incrimination may result from the testimony. ${ }^{\text {11 }}$ If the court decides against the claim of privilege, the witness is bound to answer, else he subjects himself to punishment for contempt. ${ }^{\text {t2 }}$ Moreover the order of the court adjudging hin in contempt for refusing to answer after being directed to do so, and imposing pumshment of fine or inprisonment, or both, is not subject to collateral attack. ${ }^{.3}$

Judicial expression appears to be non-existent as to whether a Congressional committee has the same power that the courts have to deny the claim of privilege where the possibility of incrimination is so remote as to be wholly insubstantial. The need for such a power in legislative investigating committees is obvious, however. To require such a committee to accept the mere statement of a witness that his answer might incriminate hin would convert a salutary protection into a ineans of abuse. Should errors be committed in the exercise of

4928 U.S. C. $\$ 634$ (1946). This "immunity bath" provision contains precisely the same defects which were found by the Supreme Court in Counselman v. Hitchcock (1892) 142 U.S. 547, to render invalid section 860 of the Revised Statutes. Section 859 (like section 860 ) provides merely that the testimony itself which was given under compulsion cannot be used as evidence against the witness in a criminal proceeding. It does not prolibit prosecution on the basis of evidence discovered as a result of that testimony. Counselman v. Hitchcock, supra, leld that the fiftl amendinent privilege against selfincrimination gives a witness a right to refuse to testify if his testimony could be used for the purpose of discovery of evidence of his crime, and that thus the immunity sought to be granted by section 860 did not extend to the limits of the privilege.

50 Cf. United States v. De Lorenzo, supra note 47.

51 Mason v. Umited States (1917) 244 U. S. 362.

52 Ibid.

53 Ex parte Kearney (U.S. 1822) 7 Wheat. 38. 
such a power, it seems reasonably clear now that the testimony erroneously exacted from the witness under compulsion could not be used either directly or indirectly to convict him of crime even in the absense of a statute to this effect. ${ }^{54}$

So the "rights" of a witness in a Congressional inquiry that are entitled to judicial protection under the doctrine of judicial review come down to these at most:

(1) A witness does not have to respond to questions in an investigation that the Congress has no Constitutional authority to make, but lawfulness of the investigation in this regard is presumed. Moreover, since the Oklahoma Press case, a greatly expanded scope of the Constitutional power of Congress to investigate seems to be recognized.

(2) A witness does not have to respond to questions that pry into his private affairs, but no affairs are private which are pertinent to a lawful investigation.

(3) While the question of pertinency is a question of law, a wide discretion must necessarily be, and in fact is, given to the inquiring body to determine this question for itself, and because of the wide scope of legislative investigations, the question of pertinency must necessarily be, and in fact is, determined by very broad standards.

(4) If a witness can claim his privilege against self-incrimination and refuse to answer, it is only because of the failure of Congress up to now to amend section 859 of the Revised Statutes in order to give the witness "absolute inmunity against future prosecution for the offence to which the question relates." 55

(5) If a witness may not lawfully refuse to answer by claiming his privilege against self-incrimination, the investigating committee nevertheless usually gives him the right to do so.

(6) If a witness claims the privilege against self-incrimination in bad faith, or because of only extremely remote possibilities of incrimination, the investigating committee (even assuming the invalidity of section 859 of the Revised Statutes) may disallow the claim and compel the witness to answer. ${ }^{5 \mathrm{~B}}$

64 Davis v. United States (1946) 328 U.S. 582; Bell v. Hood (S.D. Cal. 1947) 71 F. Supp. 813. Cf. Gibson v. United States (App. D. C. 1945) 149 F. (2d) 381, cert. denied, 326 U.S. 708; United States v. Johnson (M. D. Pa. 1947) 76 F. Supp. 538, 542.

65 Counselman v Hitchcock, supra note 49 at 586.

56 Witnesses before Congressional investigations have asserted other rights and privileges, but the rights and privileges so asserted have not received sympathetic consideration from the courts. For example, the privilege that an attorney has at common law to decline to reveal confidential communications from his chient has been asserted in Congressional investigations, but asserted unsuccessfully. Cf. Jurney v. McCracken, supra note 19. Members of the Communist Party who are called to appear before Con- 
Such are the results that have been brought forth from the labor of Kilbourn v. Thompson. Those results were inevitable, because legislative bodies do not deal with "a case" whose subject matter is confined by the narrow limits of formal pleading. They do not deal with merely a limited number of traditional "causes of action." They deal with countless ideas whose contours in the beginning, at least, are usually vague and shadowy-ideas put forth as a means of serving some public need. Those ideas must be investigated and developed in the light of countless facts in order to give them form so that their worth can be appraised. It is the job of legislative bodies to do these things, and they cannot do that job well if they are to be stopped at the threshold of their contemplations by judicial action.

Kilbourn v. Thompson sought to treat the legislative branch of the government, when exercising a power (punishment for contempt) like that which courts exercise, as if it were an inferior tribunal in the judicial hierarchy, confined in its jurisdiction to the consideration of a limited number of easily defined "cases" or subject matters. The Oklahoma Press case, as well as the nature of the legislative function itself, shows that the legislative power of inquiry cannot be so confined. Would dire consequences result if we should abandon Kilbourn v. Thompson and return the workings of the legislative process to the exclusive jurisdiction and control of the legislature? Perhaps the consequences would be beneficial. Legislators, like other menibers of the human race, are subject to the common human failing of being careless if someone else is available to review and correct their mistakes. "Interference by the courts is not conducive to the development of habits of responsibility." ${ }^{\mathrm{r} r}$ Full and final responsibility for power, on the other hand, induces care in its exercise.

gressional investigating committees usually contend (if the committee includes Southern members) that the committee is illegally constituted in that the Southern members (1) were unlawfully elected because Negroes were not permitted to vote in the primary elections, or (2) are not legally members because, by reason of section 2 of the XrVth Amendment of the Constitution, the office to wbich they were purportedly elected is non-existant. Cf. Dennis v. United States (App. D. C. 1948) 171 F. (2d) 986, cert. granted, June 27, 1949, 337 U.S. 954. Witnesses, asked if they are members of the Communist Party, etc., frequently refuse to answer on the ground of an asserted right of privacy of political beliefs alleged to be guaranteed by the First Amendment of the Constitution. This asserted right, however, has been denied by the courts. Lawson v. United States (App. D. C. 1949) 176 F. (2d) 49. See also Barsky v. United States (App. D.C. 1948) 167 F. (2d) 241, cert. denied, (1948) 334 U. S. 843. For other asserted rights see United States v. Josephson (C. C. A. 2d 1947) 165 F. (2d) 82, cert. denied (1948) 333 U.S. 838. 57 Federal Commumications Comm'n v. Pottsville Broadcasting Co. (1940) 309 U.S. $134,146$. 